\title{
Hubungan Intertekstualitas Syair Paras Nabi Dan Hikayat Nabi Bercukur
}

Moh. Muzakka

Prodi Sastra Indonesia, Fakultas Ilmu Budaya, Universitas Diponegoro

muzakkamoh@yahoo.co.id

\begin{abstract}
The existence of a text cannot be separated from the previous texts. Because, the presence of a new text is greatly influenced by previous texts. This condition is called an intertextual relationship. The presence of the text of the Prophet's shaved story on Java must have been strongly influenced by other texts that had existed in Nusantara, and could even be influenced by Arabic texts. Because, the text of the Prophet's shave story is related to the history of the Prophet who was born and lived in Arabia. This study aims to look at the intertextual relationship of the Syair Paras Nabi from the Javanese text with Hikayat Nabi Bercukur from the Malay text. To achieve this goal, this study uses a comparative approach and an intertextual approach. The results showed that the comparison of textual data to the Syair Paras Nabi text and Hikayat Nabi Bercukur text in depth found that the Syair Paras Nabi text was a transformation text of the Hikayar Nabi Bercukur text that was seen as the hypogram text.
\end{abstract}

Keywords: Intertext, hipogram, comparison, Prophet, Shave

Abstrak

Keberadaan sebuah teks tidak dapat lepas dari teks-teks sebelumnya. Sebab, hadirnya sebuah teks baru sangat terpengaruh oleh teks-teks sebelumnya. Keadaan inilah yang disebut dengan hubungan intertekstual. Hadirnya teks cerita Nabi bercukur di Jawa pasti sangat dipengaruhi oleh teks-teks lain yang telah ada di Nusantara, bahkan bisa jadi dipengaruhi oleh teks-teks Arab. Sebab, teks cerita Nabi bercukur itu terkait dengan sejarah Nabi yang lahir dan tinggal di Arab. Penelitian ini bertujuan untuk melihat hubungan intertekstual Syair Paris Nabi yang berasal dari teks Jawa dengan Hikayat Nabi Bercukur yang berasal yang berasal dari teks Melayu. Untuk mencapai tujuan itu penelitian ini menggunakan pendekatan perbandingan dan pendekatan intertekstual. Hasil penelitian menunjukkan bahwa perbandingan data-data tekstual terhadap teks Syair Paras Nabi dan teks Hikayat Nabi Bercukur secara mendalam ditemukan bahwa teks Syair Paras Nabi merupakan teks transformasi dari teks Hikayat Nabi Bercukur yang dipandang sebagai teks hipogramnya

Kata Kunci: Interteks, hipogram, perbandingan, Nabi, Bercukur

\section{Pendahuluan}

Sastra lama yang tertuang dalam naskah lama, adalah sebagian warisan dari rohani bangsa Indonesia. Warisan itu berupa ide, cita cita, dan pernyataan sikap nenek moyang yang turun-temurun (Robson, 1978:5) Warisan tersebut, berperan sangat besar dalam pembangunan mental dan spiritual bangsa, menuju pembangunan manusia seutuhnya. Di 
samping menjadi bacaan hiburan, sastra lama juga mengandung unsur pendidikan.

Pengertian sastra lama tidak terbatas pada karya-karya yang tergolong indah, tetapi lebih kompleks, yaitu semua yang tertulis dan terungkap dalam naskah-naskah lama. Kondisi yang demikian itulah menjadikan bentuk dan isinya cukup beragam. Dalam bentuk karya sastra saja (belles lettres) misalnya ditemukan naskah yang berisi hikayat, dongeng, syair, pantun, dan banyak jenis lain yang lebih spesifik lagi. Di samping itu ada banyak naskah yang membentangkan masalah undang-undang, adat istiadat, sejarah, cara membuat obat dan sebagainya (Djamaris, 1977 :21). Keanekaragaman bentuk maupun isi tersebut, dapat dilihat pada sejumlah katalog-katalog naskah yang ada.

Dalam kehidupan sastra, sastra lama juga membantu penciptaan karya sastra modern, yaitu membantu pengarang dalam pengambilan tema, penokohan, motif, dan sebagainya. Karena pengaruh dalam penciptaan karya tersebut, sering terjadi hubungan intertekstualitas dalam karya sastra. Setidaknya, ada empat aspek kesinambungan yang terjadi antara sastra lama dengan sastra baru sebagaimana yang dikemukakan A Teeuw (1982: 12), yakni (1) Banyak karya sastra modern merupakan tranformasi teks lama dalam bentuk saduran, salinan, dan sebagainya; (2) Penggunaan tema tradisional sering menonjol dalam sastra modern; (3) Dalam karya sastra modern sering terungkap dasar kebudayaan tradisional maupun konflik nilai dalam penghayatan manusia modern; dan (4) Munculnya gejala poetry reading atau dipakainya sastra sebagai performing arts.

Hubungan interteks dalam karya sastra tidak bisa dipungkiri, karena tidak ada sebuah teks manapun yang mandiri. Dalam proses penciptaan dan pembacaannya, keberadaan suatu teks tidak dapat dilakukan tanpa adanya teks-teks lain sebagai contoh, teladan, kerangka dan seterusnya (Teeuw, 1984 : 145-146). Intertekstualitas cakupannya cukup luas sebab hal itu mencakup pula bentuk-bentuk penyalinan, penyaduran, penyadapan, dan penerjemahan. Hal demikian ini sangat terkait dengan persepsi masyarakat penyambut suatu teks (1984:213). Hal ini berlaku pula pada karya sastra yang bersifat kolektisvistis yang diturunkan secara lisan maupun tulisan.

Dalam sastra Melayu, sering kita jumpai karya sastra saduran yang berasal dari satra jawa, seperti Hikayat Sri Rama, Hikayat Panji Semirang. Begitu pula sebaliknya, dalam sastra Jawa pun ditemukan karyas sastra yang berasal dari teks Melayu, misalnya Syair Paras Nabi dan Serat Anbiya. Hubungan intertekstualitas tersebut,perlu dikaji secara tekstologis, antropologis, sosiologis, maupun literer.

Sebuah kajian interteks pada sastra lama yang cukup baik telah dilakukan Umar Junus (1984), pada teks Sejarah Melayu. Dalam penelitiannya, Yunus mengungkap adanya hubungan interteks Sejarah Melayu dengan Hikayat Hang Tuah, kisah nabi-nabi, 
dan teks-teks lain. Dengan analog kajian tersebut, tulisan ini mencoba menelusuri bagaimana hubungan Syair Paras Nabi (SPN) sebagai karya sastra lama Jawa dengan Hikayat Nabi Bercukur (HNB), sebagai sastra melayu lama, dengan cara membandingkan kedua teks secara detil dan rinci.

\section{Metode Penelitian}

Penelitian ini tergolong penelitian kepustakaan sebab data-data diperoleh melalui studi pustaka dari objek yang ditelitinya. Objek material penelitian ini adalah dua teks cerita dari Jawa dan Melayu, yakni teks Syair Paras Nabi yang berbentuk puisi berbahasa Jawa dan teks Hikayat Nabi Bercukur berbentuk prosa berbahasa Melayu. Adapun objek formalnya adalah hubungan intertekstualitas kedua teks yang sama-sama menceritakan perihal Nabi bercukur. Oleh karena itu, perspektif kajian penelitian ini adalah pendekatan intertekstual melalui perbandingan kedua teks secara rinci.

Metode pengumpulan data penelitian dilakukan dengan studi kepustakaan dengan teknik membaca, mencatat, dan mengklasifikasi data-data yang terdapat dalam kedua teks tersebut. Setelah data-data terkumpul, data-data tersebut akan dianalisis dengan menggunakan pendekatan intertekstual. Pendekatan ini digunakan untuk melihat hubungan kedua teks, yakni hubungan teks transformasi dengan hipogramnya. Hal ini sebagai mana dikatakan Kristeva dalam Teeuw (1984: 145-146) bahwa tiada teks manapun hadir secara mandiri, sebab hadirnya suatu teks lebih merupakan mozaik kutipan-kutipan dari teks sebelumnya.

Adapun data-data yang telah diperoleh dalam penelitian terlebih yang telah dianalisis akan disajikan secara deskriptif. Teknik demikian akan menjadikan penelitian menjadi objektif karena data-data tersebut disajikan sesuai dengan kondisi sebenarnya.

\section{Hubungan Intertekstualitas Syair Paras Nabi (SPN) dan Hikayat Nabi Bercukur $(H N B)$}

Cerita Nabi bercukur yang terurai dalam $S P N$, sebenarnya bukan cerita asli Jawa. Namun, kehadiran teks tersebut di Jawa merupakan saduran atau transformasi teks bukan Jawa. Kondisi ini diakui oleh penulisnya dan atau penyalinnya sebagaimana data dalam teks (interne evidentie) yang menyatakan dengan tegas sebagaimana kutipan bait syair berikut :

Salah benere wallah a 'lam

Paras den syi'ir nular ing Jawan

Saking bodhone dhak bisa ngaji

Wani anyi'ir parase Nabi

$(S P N$, hal.6) 
Dari kutipan di atas cukup jelas bahwa penulis dan atau penyalin menyatakan bahwa dalam membuat syi'ir ia mengambil teks cerita yang asalnya bukan dari Jawa. Ungkapan yang demikian ini dikuatkan dengan sikap rendah hatinya karena ia merasa tidak bisa mengaji (ilmu agama). Tentang kesalahan dan kebenaran cerita itu pun pengarang menyatakan dengan ungkapan "wallahu a'lam”, yakni hanya Tuhanlah yang Mahatahu.

Meski data teks tidak menyebut berdasart teks mana ia mengambil cerita, tetapi dengan penyebutan "dhak bisa ngaji" ini menunjukkan bahwa ia mengambil dari cerita keagamaan (Islam) yang berasal dari teks Arab atau teks Melayu. Berdasarkan kajian interteks, peneliti menduga bahwa teks tersebut berasal dari teks Melayu. Peneliti berasumsi, jika penulis mengatakan tidak pandai mengaji berarti kemampun bahasa Arabnya kurang menguasai sehingga sangat kecil kemungkinannya menyadur teks cerita berbahasa Arab. Karena kurang menguasai bahasa Arab, ia bisa jadi menulis cerita berdasarkan teks lisan yang didengarnya atau bertolak dari teks cerita yang berkembang di Nusantara. Peneliti menduga bahwa penulis dan atau penyalin mengambil teks yang menggunakan huruf Arab. Hal ini cukup beralasan karena SPN ditulis dengan huruf Arab-Jawa (pegon). Terkait dengan asumsi-asumsi tersebut masih menuntut diadakannya penelitian tersendiri.

Berdasarkan penelitian Muzakka, dkk (2017) terkait dengan perkembangan cerita Nabi bercukur dalam naskah-naskah Nusantara disebutkan bahwa hadirnya teks Jawa diduga berasal dari teks Melayu, yakni bersal dari Hikayat Nabi Bercukur. Sebab, dari segi usia, SPN lebih muda dari $H N B$. Dalam teks disebutkan, $S P N$ selesai ditulis sabtu Wage, 8 Shafar $1319 \mathrm{H}$ (hal.6) atau sekitar awal abad ke-20 M; sedangkan dalam Katalogus Koleksi Naskah Melayu disebutkan, HNB tersebar luas di Melayu pertengahan abad ke-19 M (Sutaarga,1972:175-176).

Dari segi historis, penyaduran cerita $H N B$ dari Melayu ke Jawa cukup logis. Sebab, hal itu berhubungan erat dengan masuknya agama Islam ke Indonesia. Islam masuk ke Indonesia abad ke-13, melalui pedagang Gujarat. Kaum pedagang mula-mula menginjakkan kaki sambil menyebarkan agama Islam di Malaka atau Melayu, sebab waktu itu malaka merupakan pusat perdagangan yang sangat ramai. Dari Malaka, mereka menuju Gresik dan Tuban, kemudian menyebar ke seluruh pulau Jawa (Muzakka,1989). Bertolak dari data-data di atas sangat lazim kalau karya sastra Melayu pengaruh Islam, tumbuh dan berkembang lebih dahulu di banding di Jawa.

Teks $H N B$ sangat terkenal dan digemari masyarakat. Ini terbukti dengan banyaknya jumlah naskah di pelbagai daerah di Nusantara, termasuk di luar negeri. Di Museum Pusat Jakarta terdapat 7 buah manuskrip (bundel), terdiri 9 naskah. Di samping 
itu, tersimpan pula di Museum Laiden, London, dan scravenhage. Di Indonesia, cerita tersebut banyak disalin dalam berbagai bahasa, misalnya bahasa sunda, Aceh, Makasar, dan Bugis (Sutaarga dkk. 1971: 175-176; Dipodjojo, 1981: 77). Tidak ketinggalan pula teks cerita tersebut muncul dalam naskah-naskah berbahasa Jawa.

Naskah $H N B$ yang terdaftar dalam katalogus museum pusat sebanyak 9 naskah. Karena masing-masing naskah mempunyai kesamaan, baik isi maupun bahasa Maka dalam perbandingan isi, peneliti menggunakan sebuah naskah yang ditransliterasi Roosiati (1993), naskah HNB IV dengan kode MI.388 E, terdiri 16 halaman (82-89), karena ceritanya paling lengkap dan bahasanya cukup mudah (Roosiati, 1983:59).

\section{Perbandingan Nama dan Tokoh}

Meskipun kaitannya dengan isi cerita tidak terlalu penting, untuk memperoleh variasi dan spesifikasi sebuah cerita, nama dan tokoh sangat mempengaruhi terciptanya sebuah peristiwa. Pengertian nama menyangkut berbagai macam istilah yang dipakai untuk menerangkan sesuatu, meliputi nama hewan, nama tumbuhan, tempat, manusia, dan benda-benda lain, baik yang bersifat abstrak maupun konkret. Adapun tokoh merupakan pelaku sebuah cerita yang mengantarkan cerita, secara langsung maupun tidak langsung.

Nama-nama maupun tokoh-tokoh dalam teks $S P N$, banyak menunjukan kesamaan dengan $H N B$ meskipun ada pula nama-nama yang tidak sama. Adapun perbandingan nama-nama dan tokoh-tokoh sebagai berikut.

\begin{tabular}{|c|c|c|c|c|}
\hline No & Syair Paras Nabi & Hal & Hikayat Nabi Bercukur & Hal \\
\hline 1. & $\begin{array}{l}\text { Allah } \\
\text { Pangeran } \\
\text { Ilahi }\end{array}$ & $\begin{array}{l}2 \\
3 \\
4\end{array}$ & $\begin{array}{lll}\text { Allah } & & \\
\text { Ilahi, } & \text { Rabbi, } & \text { Sayyidi, } \\
\text { Maula, } & \text { Tuhanku, } & \text { Rabbal } \\
\text { Alamin } & & \end{array}$ & $\begin{array}{l}83 \\
86\end{array}$ \\
\hline 2. & $\begin{array}{l}\text { Nabi } \\
\text { Rasulullah } \\
\text { Nabi Muhammad } \\
\text { Nabi Wekasan } \\
\text { Kanjeng Gusti }\end{array}$ & $\begin{array}{l}2 \\
2 \\
2 \\
4 \\
2\end{array}$ & $\begin{array}{l}\text { Nabi } \\
\text { Rasulullah } \\
\text { Nabi Allah Muhammad } \\
\text { Khatamunabi }\end{array}$ & $\begin{array}{l}84 \\
83 \\
88 \\
85\end{array}$ \\
\hline
\end{tabular}




\begin{tabular}{|c|c|c|c|c|}
\hline & Sayyidul basyar & 6 & & \\
\hline 3. & $\begin{array}{l}\text { Kyai Abdullah } \\
\text { Raden Abdullah }\end{array}$ & $\begin{array}{l}2 \\
2\end{array}$ & & \\
\hline 4. & Makkah & 2 & Masjidil Haram & 84 \\
\hline 5. & Abwak & 2 & & \\
\hline 6. & Madinah & 2 & & \\
\hline 7. & Dewi Khadijah & 2 & & \\
\hline 8. & $\begin{array}{l}\text { Kitab Quran } \\
\text { Quranul majid }\end{array}$ & $\begin{array}{l}2 \\
86\end{array}$ & & \\
\hline 9. & $\begin{array}{l}\text { Para Sahabat, sahabat } \\
\text { papat: Abu Bakar, Umar, } \\
\text { Usman, Ali }\end{array}$ & 3 & $\begin{array}{l}\text { Sahabat empat: Abu Bakar, } \\
\text { Umar, Usman, Ali }\end{array}$ & 83 \\
\hline 10. & Abu Bakar Ratu Mukmin & 3 & $\begin{array}{l}\text { Amirul mukminin Abu } \\
\text { Bakar Shidiq }\end{array}$ & 83 \\
\hline 11. & Kuluk & 3 & Kopyah & 89 \\
\hline 12. & Perang uhud & 3 & $\begin{array}{l}\text { Perang sabilillah dengan } \\
\text { Raja Lahad }\end{array}$ & 84 \\
\hline 13. & Dina istnain & 3 & Yaumul istnain & 84 \\
\hline 14. & Malaikat Jibril & 3 & Jibrail, Habibku Jibrail & 85 \\
\hline 15. & Paras, Maras, Cukur & 3 & Bercukur & 83 \\
\hline 16. & Kayu kastuba & 4 & Sajaratul tubi & 87 \\
\hline 17. & Widadari & 5 & Anak-anak bidadari & 91 \\
\hline 18. & Munkar wa Nakir & 5 & Munkar dan Nakir & 94 \\
\hline 19. & & & Ridwan & 87 \\
\hline 20. & & & Cahaya muhammad & 90 \\
\hline 21. & & & Malakul maut & 94 \\
\hline
\end{tabular}


Dari tabel di atas, nama-nama dan tokoh-tokoh kedua teks menunjukan adanya variasi. Di samping itu, dalam menyadur cerita, penulis teks SPN cukup kreatif atau paling tidak dapat menyesuaikan dengan latar belakang budaya Jawa, meskipun latar tempat terjadinya cerita adalah Arab. Misalnya muncul local colour hadirnya nama dan istilah kanjeng gusti, pangeran, raden, kyai, dan kuluk.

\section{Perbandingan Peristiwa}

Peristiwa. Adalah peralihan suatu keadaan pada keadaan lain (Luxemburg dkk, 1984:150). Dari perbandingan peristiwa, ditemukan kesamaan dan perbedaan dua objek itu (keraf, 1980: 88). Peristiwa berhubungan erat dengan isi sebuah cerita. Sebab sebuah cerita dibangun dari berbagai peristiwa sehingga menciptakan kronologi sebuah cerita yang runtut.

Pada garis besarnya, peristiwa-peristiwa yang muncul dalam teks $S P N$ menunjukkan kesaman dan kemiripan dengan teks $H N B$. Namun, ada juga kelebihan dan kekurangannya. Ada peristiwa dalam teks $S P N$ yang tidak dijumpai dalam $H N B$. Begitu pula sebaliknya, ada peristiwa dalam teks $H N B$ yang tidak dijumpai dalam teks $S P N$.

Semua peristiwa dalam teks $S P N$ dapat ditemukan dalam teks $H N B$, kecuali peristiwa-peristiwa di bagian awal $S P N$, yakni latar belakang kehidupan tokoh Nabi Muhammad dan kedua orang tuanya (SPN,hal.2). Ada dua peristiwa dalam teks $H N B$, yang tidak ditemukan dalam teks $S P N$, yaitu peristiwa Malaikat Jibrail mendatangi Malaikat Ridwan di surga untuk minta izin memetik sajaratul tubi (HNB, hal.87-89), dan peristiwa Nabi bersabda agar umatnya senantiasa mempercayai hikmah peristiwa Nabi bercukur (HNB, hal. 95-96). Perhatikan kedua kutipan berikut.

Setelah Jibrail mendengar firman Allah Ta'ala, ia pun segera pergi ke dalam surga, Jibrail pun berseru-seru kepada Malaikat Ridwan, ...

(hal. 87-89).

Barang siapa yang menaruh surat periku ini, niscaya rahmat Allah Ta'ala pun turunlah kepadanya dari rizkinya pun tiada berkurang dianugrahi Allah Ta'ala akan dia...

(hal. 95-96).

Penggambaran peristiwa satu ke peristiwa lain, dalam teks $S P N$ tidak selengkap teks $H N B$. Kondisi demikian disebabkan oleh perbedaan bentuk kedua karya sastra tersebut. Meskipun syair dapat dimasukkkan dalam puisi naratif, tetapi prinsip kepadatan sangat 
dipertahankan dan tunduk pada kaidah-kaidah penulisan puisi yang amat terikat. Hal ini berbeda jauh dengan teks HNB yang bentuk prosa; ceritanya mengalir dan runtut membentuk bingkai cerita dan atau alur. Peristiwa-peristiwa dalam kedua teks tersebut, dapat dibandingkan sebagai berikut.

Latar Nabi bercukur dalam teks $S P N$ tidak disebut dengan jelas. Hanya peristiwa disebutkan terjadi setelah Nabi pulang dari perang Uhud, dan meneriman wahyu dari Jibril (Hal. 3). Sedangkan, dalam teks HNB latar cerita dilukiskan dengan jelas. Kejadian itu terjadi setelah Nabi pulang dari perang sabil melawan Raja Lahad, setelah sholat dan membaca Alquran di Masjidil Haram, seusai menerima wahyu dari Jibrail (hal. 84). Disebutkan pula bahwa Nabi dicukur di hadapan cahaya Muhammad (hal.90).

Hikmah Nabi bercukur dalam teks $S P N$ disebutkan bahwa orang yang mengetahui peristiwa Nabi bercukur akan diampuni segala dosanya, tak sakit saat sekarat, terlepas dari siksa kubur, diberi kebahagiaan hidup di dunia dan diakhirat, tidak kurang rezeki. Sebaliknya, orang yang tidak mempercayai peristiwa ini, berarti membenci Tuhan dan Muhammad, sehingga kelak matinya dikategorikan sebagai orang kafir (hal.5-6). Dalam teks $H N B$ disebutkan lebih lengkap, bahwa orang yang menaruh cerita ini akan diampuni segala dosanya, terpelihara dari pertanyaan malaikat Munkar dan Nakir, tidak merasa sakit saat malaikat mengambil nyawanya, terlindungi dari bermacam kejahatan, jika berperang tuhan akan memenangkannya, segala senjata tidak akan dapat melukainya, dan jika bepergian akan selamat. Sebaliknya, bagi orang yang tidak percaya, dianggap kafir dan tidak termasuk umat Muhammad (hal.93-96).

Di samping perbandingan kedua hal di atas, ada beberapa hal penting yang harus ditambahkan dalam studi intertekstual ini melalui perbandingan di luar keduanya. Dalam teks $S P N$, peristiwa Nabi bercukur terjadi setelah perang Uhud, sedangkan dalam teks $H N B$ terjadi seusai perang sabilillah dengan Raja Lahad.

Dari segi historis, latar tempat dalam teks SPN lebih dapat dipercaya sebab perang Uhud itu benar menurut fakta sejarah. Yaitu peperangan antara umat Islam dengan kaum kafir Quraisy terjadi pada tahun ketiga Hijrah (lihat Jabbar, tth dan Al-Muhdhor, 1992).

Perbedaan tampak juga dalam penyebutan jumlah rambut Nabi. Dalam teks SPN disebutkan bahwa jumlah rambut Nabi itu adalah satu kethi, tiga laksa, dan 3.333 helai (hal.5). Adapun dalam teks $H N B$ jumlah rambut Nabi adalah satu kethi, dua laksa, dan 6.666 helai.

Dalam teks $S P N$ disebutkan adanya ungkapan permohonan maaf dari penulis dan 
atau penyalin tentang benar dan salahnya dalammenyadur cerita Nabi bercukur (hal.6), Ungkapan semacam itu tidak ditemukan dalam teks $H N B$. Di samping itu, dalam teks $S P N$ tidak disebutkan waktu penyalinan teksnya, sedangkan dalam teks $H N B$ disebutkan tentang waktu penyalinan teks, yaitu selesai ditulis sabtu sore, tanggal 25 , bulan kurang jelas, $1872 \mathrm{M}$.

Dari data-data perbandingan kedua teks tersebut menunjukkan bahwa teks SPN merupakan saduran dari teks $H N B$. Hubungan demikian ini dapat dipandang sebagai intertekstualitas sebuah karya sastra.

\section{Simpulan}

Dari perbandingan data-data tekstual terhadap teks $S P N$ dan teks $H N B$ melalui analisis intertekstual secara mendalam dapat disimpulkan bahwa teks SPN merupakan teks transformasi dari teks HNB yang dipandang sebagai teks hipogramnya. Sebab, berdasarkan data interne evidentie teks $S P N$ merupakan teks saduran dari teks lain. Hal tersebut didukung oleh catatan sejarah yang menyebutkan bahwa proses Islamisasi di Jawa terjadi setelah Islamisasi di Melayu.

Ada hal yang harus dicatat di sini bahwa teks $S P N$ dan $H N B$ adalah sebagian teks yang menceritakan mengenai kehidupan Nabi yang mengandung pesan dan amanat yang kuat. Hal ini akan sangat mempengarui moral pembaca awam yang dangkal dalam pengetahuan agama Islam, bahkan dapat menyesatkannya. Namun sebagai karya imajinatif yang poliinterprestasi, tentu ada tujuan atau misi tersirat, misalnya meneladani tokoh Muhammad, mengetahui apa yang menjadi perkataan, perilaku, dan ketetapannya (hadist), sehingga dapat menyucikan jiwa dan menebalkan iman kepada Tuhan dan Rasulnya..

\section{Daftar Pustaka}

Al-Muhdhor, 1992. Kehidupan Nabi Muhammad SAW dan Amirul Mukminin Ali bin Abi Thalib. Semarang: Asy-Syifa'.

Dipodjojo, Asdi S.1981. Kesusastraan Indonesia Lama Pada Zaman Pengaruh Islam. Yogyakarta: Lukman.

Edwar, Djamaris. 1977."Filologi dan Cara Kerja Penelitihan Filologi” Bahasa dan Sastra Th 1/1.h 20-32.

Jabbar, Umar Abdul tth. Khulaskhotu Nurul Yaqiin fis Siratin Sayyidil Mursalin. Surabaya : Syarakah Makhtabah Salim Nubhan waAaulqaadin.

Keraf. Gorys 1980 Komposisi : Sebuah Pengantar Kemahiran Bahasa. Ende Flores:Nusa Indah. 
Luxemburg ddk Jan van 1984. Pengantar Ilmu Sastra (diindonesiakan oleh Dick Hartoko). Jakarta: Gramedia.

Muzakka, Moh. 1999. “Tanwirul Qari' sebagai Penyambut Teks Tajwid Tuchfatul Athfaal" Tesis Pascasarjana UGM Yogyakarta.

Muzakka, Moh dan Nur Fauzan, 2017. "Cerita Nabi Bercukur dalam Naskah-Naskah Nusantara: Kajian Tekstologis dan Resepsi”. Laporan Penelitian Fakultas Ilmu Budaya Universitas Diponegoro Semarang.

Robson, SO.1978. "Pengkajihan Sastra-Sastra Tradisional Indonesia." Dalam Bahasa dan Sastra Th. IV/16 h. 3-48.

Roosiati, meta 1983. "Hikayat Nabi Bercukur dalam Sebuah Pembicaraan. Skripsi Sarjana Universitas Diponegoro semarang.

Soekmono, R. 1981. Sejarah Kebudayaan Indonesia. Jilid 5 Yogyakarta: Kanisius.

Sutaarga dkk, M. Amir. 1972. Katalogus koleksi Naksah melayu Jakarta : Proyek Inventarisasi dan Dokumentasi Kebudayaan Nasional. Direktorat Jendral Kebudayaan.

Syair paras Nabi .tth Surabaya: Ahmad bin Sa'dun bin Nubhan Waauladihi.

Teeuw, A. 1982. Khazanah Sastra Indonesia. Jakarta: Balai pustaka.

------, 1984. Sastra dan Ilmu Sastra: Pengantar Teori Sastra. Jakarta: Pustaka Jaya.

Junus, Umar. 1984. Sejarah Melayu: Menemukan Diri Kembali. Petaling jaya:Fajar bakti SDN. BHD. 